\title{
ANALISIS PEMBENTUKAN KARAKTER SISWA DI SDN TANGERANG 15
}

\author{
Amalia Muthia Khansa ${ }^{1}$, Ita Utami ${ }^{2}$, Elfrida Devianti ${ }^{3}$ \\ Universitas Muhammadiyah Tangerang \\ amalia.muthia@umt.ac.id,ita.utami@umt.ac.id
}

\begin{abstract}
This study aims to find out what are the influences of the character of students in SDN TANGERANG 15. And find out what are the things that can affect the character education of students at the SDN. The method used in this research is descriptive qualitative method. The results of the analysis of this study note that the most important factors affecting the character of students are family, teacher, the environment, and learning media. If one of them is absent, the formation of student character will not shape properly, because the teacher, learning media, and learning models of students have a large role in shaping student character. To support this, teachers should strengthen their character. Next, the most important factor is love and support from family. Because if there is no support from the family, it will hamper a process of forming student character. That inhibits the formation of student character, namely when there is no harmony in a family.
\end{abstract}

Keywords: Student Character, Character Education, Learning Model

\begin{abstract}
Abstrak: Penelitian ini bertujuan untuk mengetahui apa saja pengaruh karakter peserta didik yang ada di SDN TANGERANG 15 . Serta mengetahui apa saja hal yang dapat mempengaruhi pendidikan karakter siswa di SDN tersebut. Metode yang digunakan dalam penelitian ini adalah metode deskriptif kualitatif. Hasil analisis dari penelitian ini diketahui bahwa faktor yang paling utama dalam mempengaruhi karakter siswa yaitu keluarga,guru, lingkungan sekitar, dan media pembelajaran. Jika salah satunya tidak ada, maka pembentukan karakter siswa tidak akan membentuk dengan semestinya, karena guru, media pembelajaran, serta model pembelajaran peserta didik memiliki peran yang besar dalam pembentukan karakter siswa. Untuk mendukung hal ini, ada baiknya para guru mengokohkan karakter yang dimiliki.Selanjutnya, faktor yang paling penting yaitu kasih sayang dan dukungan dari keluarga. Karena jika tidak ada dukungan dari keluarga, maka akan menghambat sebuah proses pembentuk karakter siswa. Yang menghambat pembentukan karakter siswa, yaitu ketika tidak adanya keharmonisan dalam sebuah keluarga.
\end{abstract}

Kata Kunci: Karakter Peserta Didik, Pendidikan Karakter, Model Pembelajaran

Fondatia : Jurnal Pendidikan Dasar

Volume 4, Nomor 1, Maret 2020; 158-179

https://ejournal.stitpn.ac.id/index.php/fondatia 


\section{PENDAHULUAN}

Membangun karakter atau yang saat ini sering kita dengar dengan sebutan carakter building sedang menjadi perhatian banyak orang terutama orang tua yang ingin mempunyai anak-anak yang berkarakter baik atau positif. Karakter yang bersifat positif yakni suatu tabiat, watak yang menunjukan nilai-nilai positif dalam kehidupan bermasyarakat, berbangsa dan bernegara.Karakter yang bersifat negatif, yakni tabiat, watak yang menunjukan nilai-nilai negatif terhadap kehidupan bermasyarakat, berbangsa dan bernegara.( Pusat Bahasa Depdiknas, 2008: 682) Pentingnya membangun karakter sejak dini karena pada prinsipnya anak dilahirkan dalam keadaan fitrah, atau jika diibaratkan bagaikan kertas putih yang tulisannya bisa diisi dengan tulisan-tulisan yang baik atau tulisan yang tidak baik. Anak menerima setiap goresan kemana ia akan diarahkan, jika diarahkan pada hal baik maka anak akan berperilaku dengan penuh kebaikan sehingga bahagia di dunia dan akhirat. Begitupun sebaliknya, jiga anak diarahkan kepada hal yang tidak baik, maka anak akan berperilaku kurang baik,untuk dirinya dan orang sekitarnya. Orangtua memang berperan penting dalam penanaman karakter anak, tetapi tidak hanya orangtua dan keluarga yang berpengaruh dalam karakter anak, tetapi lingkungan sekitarpun ikut berpengaruh.Anak tidak selamanya diam di rumah, separuh waktu anak-anak lakukan diluar rumah dengan teman-temannya.oleh karena itu tidak sedikit karakter anak terpengaruhi oleh teman-teman sepermainannya.

Selain itu untuk anak-anak yang sudah masuk dunia sekolah, mengenal teman-teman baru, yang tidak jarang juga membawa karakter-karakter yang tidak baik sehingga disadari atau tidak, diikuti oleh anak-anak yang lain karena intensitas bertemu hampir setiap hari. Maka dari lingkungan sekolahpun ikut berperan dalam pembentukan karakter anak.Sayangnya untuk beberapa sekolah belum terlalu memperhatikan karakter-karakter siswanya, biasanya pihak sekolah hanya memperhatikan prestasi akademiknya saja.Sehingga karakter siswa belum terlalu diperhatikan, terlihat masih sedikitnya sekolah-sekolah dasar yang juga mengadakan progam membangun karakter atau yang dikenal dengan sebutan (caracter building). (Jamaluddin, 2012: 170) Caracter building saat ini tengah menjadi daya tarik untuk orangtua menyekolahkan anaknya di sekolah yang memang mulai menekankan 
pentingnya membangun karakter, dimana sekolah siap menanamkan pendidikan karakter sehingga perlahan anak-anak mempunyai karakter yang baik. Karena orangtua sering kali mendapat kesulitan dalam mendidik anaknya, sehingga kebanyakan orangtua memilih sekolah yang memang mempunyai pangaruh yang baik dalam membentuk karakter anaknya menjadi manusia yang baik dan berada di jalan yang benar.Selain itu kesibukan menjadi alasan untuk orangtua ketika prilaku anak menjadi nakal.Maka orangtua memilih sekolah-sekolah yang memang juga memperhatikan karakter siswa-siswinya satu per satu.Fenomena ini juga terjadi pada orang tua yang ingin menyekolahkan anaknya di Sekolah Dasar Islam Terpadu Mata Hati yang berada di Nagreg, karena melihat sekolah tersebut mulai serius untuk mengadakan program membangun karakter siswa.Karena pihak sekolah merasa hawatir atas karakter anak terutama ketika siswa berkata kasar seperti mengeluarkan katak-kata yang tidak semestinya dikatakan. Sekolah tersebut mengedepankan 9 prinsip dalam membangun karakter yang diadakan, seperti: (1) kreatif; (2) jujur; (3) pembelajar; (4) berwawasan luas; (5) disiplin; (6) penyayang; (7) bersih; (8) bertanggung jawab; (9) menjaga. Dari sembilan prinsip itu pihak sekolah berharap bisa menghasilkan siswa siswi menjadi manusia yang baik, produktif, berguna bagi Agama dan bangsa. Tetapi untuk mencapai sembilan prinsip itu bukanlah hal yang mudah dan singkat. Pelaksanaanan pendidikan karakter dalam membangun karakter siswa sehingga menghasilkan karakter siswa yang baik bukan lah hal yang mudah dan membutuhkan waktu lama. Perlu menggunkan metode yang tepat dalam proses pendidikan karakternya. Di Sekolah Islam Terpadu Mata Hati salah satu metode yang digunakan dalam membangun karakter adalah dengan cara bimbingan klasikal. Layanan ini masih belum banyak dilakukan disekolah yang lain. Bukan hanya di Sekolah Dasar saja, tetapi SMP dan SMA pun masih sedikit yang menggunakan metode bimbingan klasikal ini.Termasuk di daerah Nagreg pun hanya SD Islam Terpadu Mata Hati yang sudah mempunyai guru BK dan menggunakan metode bimbingan klasikal.

Karakter merupakan hal sangat esensial dalam berbangsa dan bernegara, oleh sebab itu hilangnya karakter akan menyebabkan hilangnya generasi penerus bangsa. Karakter juga memiliki fungsi seabagai penggerak dan kekuatan sehingga bangsa ini 
tidak terombang-ambing. Di sisi lain, karakter tidak datang daengan sendirinya, namun harus dibangun dan dibentuk untuk menjadikan suatu bangsa bermartabat ( Pemerintah Republik Indonesia, 2010: 3) uraian tersebut meninggalkan pesan bahwa karakter harus diwujudkan secara nyata melalui tahapan-tahapan tertentu. Salah satu tahapan yang dapat dilakukan yaitu membangun karakter yang kuat, melalui pendidikan guna membuat bangsa ini memiliki karakter yang kuat, bermartabat, dan memiliki great civilitation.

Karakteristik siswa merupakan salah satu variabel yang berpengaruh terhadap keberhasilan sistem instruksional. (Sanjaya 2012:17). Variabel ini definisikan sebagai aspek-aspek atau kualitas individu siswa. Aspek-aspek berkaitan dapat berupa bakat, minat, sikap, motivasi belajar, gaya belajar, kemampuan berfikir, dan kemampuan awal (hasil belajar yang telah dimilikinya (Atmowijo, 2008:95). Karakteristik siswa akan amat berpengaruh dalam pemilihan strategi pengelolaan, yang berkaitan dengan bagaimana menata pembelajaran, khususnya komponen-komponen strategi pembelajaran, agar sesuai dengan karakteristik individu siswa (Uno, 2009:58).

Pendidikan memiliki dua tujuan besar yaitu membantu anak-anak menjadi pintar dan membantu mereka menjadi baik (Lickona, 2013:6).Hal tersebut menunjukan bahwa pendidikan merupakan sarana strategis dalam pembentukan karakter karena mempunyai tujuan melahirkan insan yang cerdas dan berkarakter. Hal tersebut pernah dikatakan oleh Martin Luther King, yaitu: intelligence plus character...that is the goal of true education (kecerdasan yang berkarakter... adalah tujuan akhir pendidikan yang sebenarnya (muslich, 2011: 75)

Pembangunan karakter penting bagi bangsa Indonesia, karena untuk melahirkan generasi bangsa yang tangguh. Bung Karno menegaskan bahwa "bangsa ini harus dibangun dengan mendahulukan pembangunan karakter (character building) karena character building inilah yang akan membuat Indonesia menjadi bangsa yang besar, maju dan jaya, serta bermatabat" (Samani dan Hariyanto 2011: 1-2). Sekolah sebagai sarana strategis untuk membangun generasi bangsa harus melaksanakan pendidikan karakter, karena karakter bangsa Indonesia lemah.Karakter bangsa yang lemah harus ditanggulangi dan diperbaiki. Seperti yang diungkapkan Listyarti (2014: 5) "karakter lemah bangsa Indonesia yang harus diperbaiki yaitu penakut, feodal, 
penindas, koruptif, tidak logis, meremehkan mutu, suka menerabas, tidak percaya diri sendiri, tidak berdisiplin, mengabaikan tanggung jawab, hipokrit, lemah kreatifitas dan tak punya malu." Selain itu bangsa kita telah lama memiliki kebiasaan-kebiasaan kurang kondusif untuk membangun bangsa yang unggul. Kebiasaan tersebut meliputi membuang sampah tidak pada tempatnya, gaya hidup konsumtif, kurang menghargai perbedaan, tidak suka membaca, mudah mengeluh, dan kabiasaan buruk lainnya.

Karakter merupakan aspek utama dalam membentuk kualitas seseorang untuk dapat menjadi insan yang mulia.Apabila kualitas diri seseorang baik dan senantiasa ditumbuh kembangkan, maka seseorang tersebut dapat menjadi manusia yang bermanfaat bagi lingkungan sekitar dan kemajuan bangsa.Hidayatullah (2010: 16) mengemukakan bahwa "karakter adalah kualitas atau kekuatan mental atau moral, akhlak atau budi pekerti individu yang merupakan kepribadian khusus yang menjadi pendorong atau penggerak serta yang membedakan dengan individu lain." Sementara itu, Samani dan Hariyanto (2012: 46) memaknai “pendidikan karakter sebagai suatu sistem penanaman nilai-nilai karakter kepada warga sekolah yang meliputi komponen pengetahuan, kesadaran atau kemampuan dan tindakan untuk melaksanakan nilainilai tersebut baik terhadap Tuhan Yang Maha Esa, diri sendiri, sesama, lingkungan maupun kebangsaan sehingga menjadi manusia insan kamil.” Dengan begitu dapat diartikan pendidikan karakter harus diupayakan oleh satuan pendidikan, untuk meningkatkan mutu penyelenggaraan dan hasil pendidikan di sekolah yang mengarah pada pencapaian pembentukan karakter siswa.

Karakter adalah tabiat atau kebiasaan. Karakter dipandang sebagai solusi untuk diterapkan dalam setiap lembaga pendidikan. Mengingat sistem pendidikan yang ada saat ini masih mementingkan aspek akademis semata. Padahal pendidikan seharusnya mengembangkan potensi yang dimiliki peserta didik secara komprehensif. Kecerdasan intelektual, emosional dan spiritual perlu dikembangkan secara bersama. Jika kecerdasan intelektual saja yang dikembangkan akibatnya kecerdasan ini akan terkikis oleh perkembangan zaman karena rapuhnya kecerdasan emosional dan spiritual. Kenyataannya masih banyak sekolah yang menganak emaskan kecerdasan intelektual peserta didiknya. Karakter perlu untuk digaungkan sehingga lahir kesadaran bersama akan pentingnya membangun karakter generasi bangsa yang 
kokoh dalam menghadapi perkembangan zaman. Arus globalisasi telah membawa perubahan yang signifikan dalam segala aspek kehidupan masyarakat. Namun perubahan tersebut cenderung mengarah pada kemerosotan moral dan akhlak.

Penanaman pendidikan karakter penting dilaksanakan di sekolah, agar mengarahkan dan menguatkan siswa untuk berkarakter. Pentingnya pendidikan karakter diamanatkan sebagaimana tertulis dalam UU Nomor 20 Tahun 2003 tentang Sistem Pendidikan Nasional pasal 3 menyatakan bahwa: Pendidikan nasional berfungsi mengembangkan kemampuan dan membentuk watak serta peradaban bangsa yang bermartabat dalam rangka mencerdaskan kehidupan bangsa, bertujuan untuk berkembangnya potensi siswa agar menjadi manusia yang beriman dan bertakwa kepada Tuhan Yang Maha Esa, berakhlak mulia, sehat, berilmu, cakap, kreatif, mandiri, dan menjadi warga negara yang demokratis serta bertanggung jawab.

Pembentukan karakter melalui pendidikan karakter pada dasarnya berangkat dari berbagai macam permasalahan yang menyangkut generasi muda di era globalisasi sekarang ini. Kondisi putra-putri bangsa semakin memprihatinkan dilihat dari cara pergaulan mereka, gaya hidup, penurunan semangat belajar, masalah narkoba, bahkan kriminalitas yang menjerat anakanak di bawah umur seakan sudah menjadi hal yang biasa belakangan ini. Melihat dari situasi kebanyakan generasi muda saat ini dan dengan adanya wacana pembentukan karakter pada pribadi bangsa, maka muncullah berbagai variasi dari pendidikan karakter. Dirumuskannya pendidikan karakter adalah guna membentuk bangsa yang kuat dan berkarakter, bermartabat, serta disegani di dunia internasional.Untuk mendapatkan bangsa dan negara semacam itu perlu penerapan pendidikan karakter yang benar.Di Indonesia sendiri pendidikan karakter telah cukup lama didengungkan dalam dunia pendidikan. Menurut Hamid (2013: 29) Pendidikan karakter yang kemudian menjadi character education menjadi tema populer saat ini, terutama setelah dicanangkan oleh Kementerian Pendidikan pada 2 Mei 2010. Menteri pendidikan nasional mendeklarasikan dimulainya pendidikan karakter bangsa. Kementerian Pendidikan Nasional (dalam Gunawan, 2012: 33) mengemukakan ada 18 nilai-nilai karakter yang akan ditanamkan kepada generasi muda Indonesia. Karakter-karakter ini yaitu: religius, jujur, toleransi, disiplin, kerja keras, kreatif, mandiri, demokratis, rasa ingin tahu, semangat kebangsaan, cinta tanah 
air, menghargai prestasi, komunikatif/bersahabat, cinta damai, gemar membaca, peduli lingkungan, peduli sosial, dan tanggung jawab.

Para pakar pendidikan pada umumnya sependapat tentang pentingnya upaya peningkatan pendidikan karakter pada jalur pendidikan formal.Namun demikian, ada perbedaan-perbedaan pendapat di antara mereka tentang pendekatan dan model pendidikannya.Sebagian pakar cenderung menggunakan pendekatan pendidikan moral dari negara barat seperti perkembangan moral kognitif, pendekatan analisis nilai, dan pendekatan klarifikasi nilai. Sebagian yang lain cenderung menggunakan pendekatan tradisional, yakni melalui penanaman nilai-nilai sosial tertentu dalam diri siswa (Gunawan, 2012: 24). Pembentukan dan pendidikan karakter siswa secara intensif merupakan suatu keharusan dan tidak bisa ditunda.Hal ini dapat dilakukan apabila semakin banyak waktu siswa untuk berada di sekolah.Sehingga hal tersebut memungkinkan guru untuk memberikan arahan, pembiasaan, dan bimbingan kepada siswa.Misal bagaimana harus bersikap terhadap yang lebih tua, lebih muda, dan teman sebayanya. Pentingnya pendidikan karakter yang dilaksanakan oleh sekolah sejalan dengan pendapat dari Pala (2012: 23) yang menyatakan "To be effective, character education mustinclude the entire school community and must be infused throughout the entireschool curriculum and culture", pendapatnya ini dapat diartikan bahwa agar dapat berjalan efektif, pendidikan karakter harus dimasukkan ke dalam lingkungan sekolah dan harus ditanamkan melalui kurikulum dan budaya sekolah.

Pentingnya karakter menjadi persoalan yang sangat serius dibahas.Pemerintah telah menyisipkan pendidikan karakter dalam kurikulum (2013:5).Pendidikan karakter dalam kurikulum 2013 dimasukan dalam komptensi inti bagian 1 dan 2.Komptensi yang berkenaan dengan sikap keagamaan dan sosial dikembangkan secara tidak langsung (inderect teaching) yaitu pada waktu peserta didik belajar tentang pengetahuan (Kompetensi Inti 3) dan penerapan pengetahuan (Kompetensi 4). Sesuai dengan rancangan kurikulum 2013 yakni memusatkan perhatian besar pada karakter di sekolah dasar sebelum anak memasuki jenjang pendidikan SMP dan seterusnya. Nilai -nilai karakter yang dikembangkan dalam kemendiknas ada delapan belas karakter antara lain : karakter religius, jujur, disiplin, toleransi, kerja keras, kreatif, mandiri, demokratis, rasa ingin tahu, semangat kebangsaan, cinta tanah air, 
menghargai prestasi, bersahabat, cinta damai, gemar membaca, peduli lingkungan, peduli social, dan bertanggung jawab. Pada jenjang sekolah dasar khususnya kelas rendah diharapkan siswa memiliki lima karakter dasar, yaitu: religius, jujur, disiplin, mandiri, dan tanggung jawab. Tuntunan, hal yang paling sederhana yang bisa dilakukan adalah dengan cara menjadi contoh/figur/tauladan yang baik bagi peserta didik. Pendidikan karakter bukan sekedar deretan ilmu, pengetahuan namun aksi positif dari pengetahuan yang sudah di dapat.

Faktor-faktor pembentukan krakter ialah akhi-psikis yang mengekspresikan diri dalam bentuk tingkah laku dan keseluruhan dari manusia.Sebagian disebabkan bakat pembawaan dan sifat-sifat hereditas sejak lahir.Sebagian lagi dipengaruhi oleh lingkungan.Karakter ini menampilkan manusia yang menyolok, karakteristik, yang unik dengan ciri-ciri individual.

Dalam Mansur Muslich dijelaskan bahwa karakter merupakan kualitas moral dan mental seseorang yang pembentukannya dipengaruhi oleh faktor bawaan (fitrah, nature) dan lingkungan (sosialisasi pendidikan, nurture). Potensi karakter yang baik dimiliki manusia sebelum dilahirkan, tetapi potensi-potensi tersebut harus dibina melalui sosialisasi dan pendidikan sejak usia dini.

Karakter tidak terbentuk begitu saja, tetapi terbentuk melalui beberapa faktor yang mempengaruhi, yaitu: faktor biologis dan faktor lingkungan.

a. Faktor Biologis

Faktor Biologis yaitu faktor yang berasal dari dalam diri orang itu sendiri.Faktor ini berasal dari keturunan atau bawaan yang dibawa sejak lahir dan pengaruh keturunan dari salah satu sifat yang dimiliki salah satu dari keduanya.

b. Faktor Lingkungan

Disamping faktor-faktor hereditas (faktor Endogin) yang relatif konstan, sifatnya, yang terdiri antara lain atas lingkungan hidup, pendidikan, kondisi dan situasi hidup dan kondisi masyarakat (semuanya merupakan faktor

Eksogin) semuanya berpengaruh besar terhadap pembentukan karakter. 
Proses pembentukan karakter

Proses pembentukan karakter menurut beberapa ahli, sebagai berikut:

a. Menurut ahli Ratna Megawangi mengatakan bahwa sebuah proses yang berlangsung seumur hidup. Anak-anak akan tumbuh menjadi pribadi yang berkarakter jika Ia tumbuh pada lingkungan yang berkarakter pula. Sejatinya ada tiga pihak yang mempunyai peran penting terhadap sebuah pembentukan karakter anak yaitu: keluarga, sekolah dan lingkungan.ketiga pihak itulah yang harus memiliki sebuah hubungan yang sinergis.

b. Menurut Anis Matta dalam membentuk karakter muslim menyebutkan beberapa kiadah dalam pembentukan karakter:

- Pertama, kaidah kebertahapan dalam membentuk dan mengembangkan karakter itu tidak bisa secara instan ataupun terburuburu dalam mendapatkan sebuah hasil.

- Kedua, yaitu kaidah kesinambungan kalau kita lihat dari sudut sebuah pembiasaan ataupun latihan, walaupun hanya dengan porsi yang sedikit yang terpenting adalah ksinambungannya atau continue.

- Ketiga, kaidah momentum yaitu berbagai momentum pristiwa untuk sebuah fungsi pendidikan dan latihan.

- Keempat, kaidah motivasi intrinsik yaitu karakter yang kuat akan terbentuk sempurna jika yang menyertainya benar-benar lahir dari dalam diri sendirinya.

- Kelima, kaidah pembimbingan yaitu dalam pembentukan karakter ini tidak bisa dilakukan tanpa seorang guru atau pembimbing.

\section{Langkah-Langkah Mengubah Karakter:}

Dengan mengetahui tahapan, metode dan proses pembentukan karakter, maka bisa diketahui bahwa akar dari prilaku atau karakter itu adalah cara berpikir dan cara merasa seseorang. Sehingga untuk mengubah karakter seseorang, kita bisa melakukan tiga langkah berikut: 
- Langkah pertama adalah melakukan perbaikan dan pengembangan cara berpikir yang kemudian disebut terapi kognitif, dimana pikiran menjadi akar dari karakter seseorang.

- Langkah kedua melakukan perbaikan dan pengembangan cara merasa yang disebut dengan terapi mental, karena mental adalah batang karakter yang menjadi sumber tenaga jiwa seseorang.

- Langkah ketiga melakukan perbaikan dan pengembangan cara bertindak yang disebut dengan terapi fisik, yang mendorong fisik menjadi pelaksana dari arahan akal dan jiwa.

Hidup dizaman modern ini semua serba ada, baik dan buruk, halal haram, benar salah nyaris campur menjadi satu, sulit untuk dibedakan. Maka sebaikbaik orang yang dapat memilah dan memilih suatu perbuatan yang baik, karena perbuatan baik ini akan berdampak pada prilaku manusia.

\section{Hal-hal yang perlu diperhatikan dalam membentuk karakter:}

Dalam proses pembentukan karakter, ada beberapa hal yang harus diperhatikan. Diantara nya :

a. Pembiasaan tingkah laku sopan

Sopan santun atau etiket adalah akhlak yang bersifat lahir. Ukuran sopan santun terletak pada cara pandang suatu masyarakat. Oleh karena itu cara pandang sopan-santun dan sikap suatu daerah mungkin berbeda dengan cara pandang masyarakat yang lain. Sopan santun diperlukan ketika sesorang berkomunikasi dengan orang lain, dengan penekanan utama pertama kepada orang yang lebih tua atau guru atau atasan, kedua kepada orang yang lebih muda, anah buah, anak, murid, bawahan dan sebagainya, ketiga kepada orang yang setingkat atau sebaya, seusia atau setingkat status sosial.

Disamping itu sopan santun juga berlaku ketika berkomunikasi dengan kawan atau lawan.Komunikasi dengan lawan memerlukan kekuatan diplomatis yang lebih kuat dibandingkan dengan perilaku kasar. Kesopanan bisa menambat hati lawan, sebaliknya kekerasan akan menimbulkan dendam. 
b. Kebersihan, kerapian dan ketertiban

Pengetahuan tentang hubungan kebersihan dengan lingkungan dibentuk melalui proses pendidikan, tetapi kepekaan terhadap kebersihan dibangun melalui proses pembiasaan sejak kecil. Konsisitensi orang tua terhadap keharusan anak untuk cuci tangan sebelum makan, cuci kaki sebelum tidur, mandi dan gosok gigi secara tertur, menyapu lantai dan halaman rumah,buang sampah di tempat sampah, menempatkan sepatu ditempatnya, merapikan baju dan buku dikamarnya. Merapikan tempat tidur setiap bangun tidur, adalah merupakan pekerjaan membiasakan anak pada hidup bersih hingga kedasaran akan kebersihan itu menjadi bagian dari kepribadiannya. Pada usia remaja kebersihan harus didukung oleh pengetahuan empirik, misalnya melihat benda dan air kotor, tangan kotor dan sebagainya dengan mikroskup sehingga bisa menyaksikan sendiri kumankuman penyakit pada sesuatu yang kotor tersebut. Adapun perilaku bersih pada masyarakat diwujudkan dengan pengaturan yang bersistem, misalnya sistem pemeliharaan kebersihan umum lengkap dengan sarana yang tesedia, sistem sanitasi, sistem pembuangan limbah ditempat umum kemusian didukung dengan peraturan yang menjamin kelangsungan hidup bersih dan tertib.

c. Kejujuran

Kejujuran merupakan sifat terpuji. Dalam bahasa arab disebut dengan istiah siddq dan amanah. Siddiq artinya benar, amanah artinya dapat dipercaya, ciri orang jujur adalah tidak suka bohong, meski demikian jujur yang berkonotasi positif berbeda dengan jujur dalam arti lugu dan polos.Dalam sifat amanah mengandung arti cerdas, yakni kejujuran yang disampaikan dengan bertanggung jawab. Jujur bukan berarti mengatakan semua yang diketahui apa adanya, tetapi

mengatakan apa yang diketahui sepanjang mengandung kebaikan dan tidak menyebutnya jika diperkirakan memabawa akibat buruk bagi dirinya dan orang lain. 
d. Disipilin

Tingkah laku disiplin dilakukan karena mengikuti suatu komitmen.

Disiplin bisa berhubungan dengan kejujuran, bisa juga tidak.Kejujuran juga diwariskan oleh genetika orang tuannya, terutama ketika anak masih dalam kandungan, secara psikologis dapat menetas pada anaknya. Keharmonisan orang tua didalam rumah akan sangat berpengaruh dalam membentuk watak dan kepribadian anak-anak pada umur perkembangannya. Ketika anak masih kecil, pantang orang tua bebohong kepada anaknya, karena kebohongan yang diarasakan oleh anak akan menimbulkan kegelisahan serta merusak tatanan psikologi seorang anak.

Pada anak usia kelas IV SD hingga SLTP, kejujuran sebaiknya dibiasakan sejalan dengan kedisplinan hidup, disiplin belajar, disiplin ibadah, displin bekerja membantu orang tua di rumah, disiplin keuangan dan dan disiplin agenda harian anak. Pada anak usia SMA kejujuran dan kedisiplinan yang ditanamkan harus sudah disertai alasan yang rasional, baik dalam kehidupan dalam rumah tangga, sekolah maupun dilingkungan masyarakat. Sistem punishment dan reward sudah bisa diterapkan secara rasional. Pada usia mahasiswa, kejujuran dan kedisiplinan dinisyakan melalui pemberian kepercayaan dalam berbagai tanggungjawab.kepada mereka sudah ditekankan komitmen dan substansi, sementara prosedur dan teknik mungkin harus sudah diserahkan kepada seni dan kreatifitas mereka.

\section{Dampak Pendidikan Karakter:}

Berdasarkan buletin Character Educator, yang diterbitkan oleh Character Education Partnership, diuraikan bahwa hasil studi Dr. Marvin Berkowitz dari University of Missouri- St. Louis, menunjukan peningkatan motivasi siswa sekolah dalam meraih prestasi akademik pada sekolah-sekolah yang menerapkan pendidikan karakter. Kelas-kelas yang secara komprehensif terlibat dalam pendidikan karakter menunjukkan adanya penurunan drastis pada perilaku negatif siswa yang dapat menghambat keberhasilan akademik.

Begitu juga halnya dengan buku yang berjudul Emotional Intelligence and School Success (Joseph Zins, et.al, 2001).Buku ini mengkompilasikan 
berbagai hasil penelitian tentang pengaruh positif kecerdasan emosi anak terhadap keberhasilan di sekolah.Dikatakan bahwa ada sederet faktor-faktor resiko penyebab kegagalan anak di sekolah. Faktor-faktor resiko yang disebutkan ternyata bukan terletak pada kecerdasan otak, tetapi pada karakter, yaitu rasa percaya diri, kemampuan bekerja sama, kemampuan bergaul, kemampuan berkonsentrasi, rasa empati, dan kemampuan berkomunikasi.

Hal itu sesuai dengan pendapat Daniel Goleman tentang keberhasilan seseorang di masyarakat, ternyata 80 persen dipengaruhi oleh kecerdasan emosi, dan hanya 20 persen ditentukan oleh kecerdasan otak (IQ). Seorang siswa yang mempunyai masalah dalam kecerdasan emosinya, akan mengalami kesulitan belajar, bergaul dan tidak dapat mengontrol emosinya. Siswa yang bermasalah ini sudah dapat dilihat sejak usia pra-sekolah, dan kalau tidak ditangani akan terbawa sampai usia dewasa. Sebaliknya para remaja yang berkarakter akan terhindar dari masalah-masalah umum yang dihadapi oleh remaja seperti kenakalan, tawuran, narkoba, miras, perilaku seks bebas, dan sebagainya.

Beberapa negara yang telah menerapkan pendidikan karakter sejak pendidikan dasar di antaranya adalah; Amerika Serikat, Jepang, Cina, dan Korea.Hasil penelitian di negara-negara ini menyatakan bahwa implementasi pendidikan karakter yang tersusun secara sistematis berdampak positif pada pencapaian akademis.

\section{Prinsip Pendidikan Karakter:}

Berikut ini adalah 11 prinsip-prinsp pendidikan karakter.Komunitas sekolah mengembangkan dan meningkatkan nilai-nilai inti etika dan kinerja sebagai landasan karakter yang baik.Sekolah berusaha mendefinisikan "karakter" secara komprehensif, di dalamnya mencakup berpikir (thinking), merasa (feeling), dan melakukan (doing). Sekolah menggunakan pendekatan yang komprehensif, intensif, dan proaktif dalam pengembangan karakter.Sekolah menciptakan sebuah komunitas yang memiliki kepedulian 
tinggi.(caring) Sekolah menyediakan kesempatan yang luas bagi para siswanya untuk melakukan berbagai tindakan moral (moral action).

Sekolah menyediakan kurikulum akademik yang bermakna dan menantang, dapat menghargai dan menghormati seluruh peserta didik, mengembangkan karakter mereka, dan berusaha membantu mereka untuk meraih berbagai kesuksesan.Sekolah mendorong siswa untuk memiliki motivasi diri yang kuat Staf sekolah ( kepala sekolah, guru dan TU) adalah sebuah komunitas belajar etis yang senantiasa berbagi tanggung jawab dan mematuhi nilai-nilai inti yang telah disepakati. Mereka menjadi sosok teladan bagi para siswa. Sekolah mendorong kepemimpinan bersama yang memberikan dukungan penuh terhadap gagasan pendidikan karakter dalam jangka panjang. Sekolah melibatkan keluarga dan anggota masyarakat sebagai mitra dalam upaya pembangunan karakter Secara teratur, sekolah melakukan asesmen terhadap budaya dan iklim sekolah, keberfungsian para staf sebagai pendidik karakter di sekolah, dan sejauh mana siswa dapat mewujudkan karakter yang baik dalam kehidupan sehari-hari.

\section{Indikator Pendidikan Karakter:}

Pendidikan karakter bangsa bisa dilakukan dengan pembiasaan nilai moral luhur kepada siswa dan membiasakan mereka dengan kebiasaan yang sesuai dengan karakter kebangsaan. Berikut 18 indikator pendidikan karakter bangsa sebagai bahan untuk menerapkan pendidikan karakter pada siswa:

a. Religius, adalah sikap dan perilaku yang patuh dalam melaksanakan ajaran agama yang dianutnya, toleran terhadap pelaksanaan ibadah agama lain, serta hidup rukun dengan pemeluk agama lain.

b. Jujur, adalah perilaku yang didasarkan pada upaya menjadikan dirinya sebagaiorang yang selalu dapat dipercaya dalam perkataan, tindakan, dan pekerjaan.

c. Toleransi, adalah sikap dan tindakan yang menghargai perbedaan agama, suku,etnis,pendapat, sikap, dan tindakan orang lain yang berbeda dari dirinya 
d. Disiplin, adalah tindakan yang menunjukkan perilaku tertib dan patuh pada berbagai ketentuan dan peraturan.

e. Kerja Keras, adalah perilaku yang menunjukkan upaya sungguh-sungguh dalam mengatasi berbagai hambatan belajar, tugas dan menyelesaikan tugas dengan sebaik-baiknya.

f. Kreatif, adalah berpikir dan melakukan sesuatu untuk menghasilkan cara atau hasil baru dari sesuatu yang telah dimiliki.

g. Mandiri, adalah sikap dan prilaku yang tidak mudah tergantung pada orang lain dalam menyelesaikan tugas-tugas.

h. Demokratis, adalah cara berpikir, bersikap, dan bertindak yang menilai sama hak dan kewajiban dirinya dan orang lain.

i. Rasa ingin tahu, adalah sikap dan tindakan yang selalu berupaya untuk mengetahui lebih mendalam dan meluas dari sesuatu yang dipelajari, dilihat, dan didengar.

j. Semangat kebangsaan, adalah cara berpikir, bertindak, dan berwawasan yang menempatkan kepentingan bangsa dan negara di atas kepentingan diri dan kelompoknya.

k. Cinta tanah air, adalah cara berpikir, bersikap, dan berbuat yang menunjukkan kesetiaan, kepedulian, dan penghargaan yang tinggi terhadap bahasa, lingkungan fisik, sosial, budaya, ekonomi, dan politik bangsa.

1. Menghargai prestasi, adalah sikap dan tindakan yang mendorong dirinya untuk menghasilkan sesuatu yang berguna bagi masyarakat, mengakui, dan menghormati keberhasilan orang lain.

m. Bersahabat/komuniktif, adalah tindakan yang memperlihatkan rasa senang berbicara, bergaul, dan bekerja sama dengan orang lain.

n. Cinta damai, adalah sikap, perkataan, dan tindakan yang menyebabkan orang lain merasa senang dan aman atas kehadiran dirinya

o. Gemar membaca, adalah kebiasaan menyediakan waktu untuk membaca berbagai bacaan yang memberikan kebajikan bagi dirinya. 
p. Peduli lingkungan, adalah sikap dan tindakan yang selalu berupaya mencegah kerusakan pada lingkungan alam di sekitarnya dan mengembangkan upaya-upaya untuk memperbaiki kerusakan alam yang sudah terjadi.

q. Peduli sosial, adalah sikap dan tindakan yang selalu ingin memberi bantuan pada orang lain dan masyarakat yang membutuhkan.

\section{Tips untuk Menerapkan Pendidikan Karakter di Sekolah:}

Berikut adalah tips untuk sukses menerapkan pendidikan berbasis karakter di sekolah.

a. Memiliki nilai-nilai yang dianut dan disampaikan kepada seluruh stake holder sekolah melalui berbagai media : buku panduan untuk orang tua (dan siswa), news untuk orang tua, pelatihan.

b. Staf pengajar dan administrasi termasuk tenaga kebersihan dan keamanan mendiskusikan nilai-nilai yang dianut, Nilai-nilai ini merupakan penjabaran dari nilai-nilai yang diyakini sekolah.

c. Siswa dan guru mengembangkan nilai-nilai yang dianut di kelas masingmasing.

d. Memberikan dilema-dilema dalam mengajarkan suatu nilai, misalnya tentang kejujuran.

e. Pembiasaan penerapan nilai di setiap kesempatan

f. Mendiskusikan masalah yang terjadi apabila ada pelanggaran

g. Mendiskusikan masalah dengan orang tua apabila masalah dengan anak adalah masalah besar atau masalahnya tidak selesai. 


\section{Pentingnya Pendidikan Karakter Bagi Anak Sekolah Dasar}

Pendidikan karakter pada anak Sekolah Dasar, dewasa ini sangat di perlukan di karenakan saat ini Bangsa Indonesia sedang mengalami krisis karakter dalam diri anak bangsa. Karakter di sini adalah watak, tabiat, akhlak, atau kepribadian seseorang yang terbentuk dari hasil internalisasi berbagai kebajikan yang diyakini dan digunakan sebagai landasan untuk cara pandang, bepikir, bersikap dan bertindak. Kebajikan tersebut berupa Sejumlah nilai moral, dan norma, seperti jujur, berani bertindak, dapat dipercaya, hormat pada orang lain, disiplin, mandiri, kerja keras, kreatif.

Berbagai permasalahan yang melanda bangsa belakangan ini ditengarai karena jauhnya kita dari karakter.Jati diri bangsa seolah tercabut dari akar yang sesungguhnya. Sehingga pendidikan karakter menjadi topik yang hangat di bicarakan belakangan ini.Menurut Prof Suyanto Ph.D dalam web yang penulis akses, karakter adalah cara berpikir dan berperilaku yang menjadi ciri khas tiap individu untuk hidup dan bekerja sama, baik dalam lingkup keluarga, masyarakat, bangsa dan negara. Individu yang berkarakter baik adalah individu yang bisa membuat keputusan dan siap mempertanggungjawabkan tiap akibat dari keputusan yang ia buat.

Pembentukan karakter merupakan salah satu tujuan pendidikan nasional.Pasal I UU Sisdiknas tahun 2003 menyatakan bahwa di antara tujuan pendidikan nasional adalah mengembangkan potensi peserta didik untuk memiliki kecerdasan, kepribadian dan akhlak mulia. Amanah UU Sisdiknas tahun 2003 itu bermaksud agar pendidikan tidak hanya membentuk insan Indonesia yang cerdas, namun juga berkepribadian atau berkarakter, sehingga nantinya akan lahir generasi bangsa yang tumbuh berkembang dengan karakter yang bernafas nilainilai luhur bangsa serta agama.

Pendidikan karakter di nilai sangat penting untuk di mulai pada anak usia dini atau Sekolah Dasar karena pendidikan karakter adalah proses pendidikan yang ditujukan untuk mengembangkan nilai, sikap, dan perilaku yang memancarkan akhlak mulia atau budi pekerti luhur. Nilai-nilai positif dan yang seharusnya dimiliki seseorang menurut ajaran budi pekerti yang luhur adalah amal saleh, 
amanah, antisipatif, baik sangka, bekerja keras, beradab, berani berbuat benar, berani memikul resiko, berdisiplin, berhati lapang, berhati lembut, beriman dan bertaqwa, berinisiatif, berkemauan keras, berkepribadian, berpikiran jauh ke depan, bersahaja, bersemangat, bersifat konstruktif, bersyukur, bertanggung jawab, bertenggang rasa, bijaksana, cerdas, cermat, demokratis, dinamis, efisien, empati, gigih, hemat, ikhlas, jujur, kesatria, komitmen, kooperatif, kosmopolitan (mendunia), kreatif, kukuh hati, lugas, mandiri, manusiawi, mawas diri, mencintai ilmu, menghargai karya orang lain, menghargai kesehatan, menghargai pendapat orang lain, menghargai waktu, patriotik, pemaaf, pemurah, pengabdian, berpengendalian diri, produktif, rajin, ramah, rasa indah, rasa kasih sayang,rasa keterikatan, rasa malu, rasa memiliki, rasa percaya diri, rela berkorban, rendah hati, sabar, semangat kebersamaan, setia, siap mental, sikap adil, sikap hormat, sikap nalar, sikap tertib, sopan santun, sportif, susila, taat asas, takut bersalah, tangguh, tawakal, tegar, tegas, tekun, tepat janji, terbuka, ulet, dan sejenisnya.

Sejatinya pendidikan karakter ini memang sangat penting dimulai sejak dini. Sebab falsafah menanam sekarang menuai hari esok adalah sebuah proses yang harus dilakukan dalam rangka membentuk karakter anak bangsa. Pada usia kanakkanak atau yang biasa disebut para ahli psikologi sebagai usia emas (golden age) terbukti sangat menentukan kemampuan anak dalam mengembangkan potensinya. Hasil penelitian menunjukkan bahwa sekitar 50 persen variabilitas kecerdasan orang dewasa sudah terjadi ketika anak berusia empat tahun. Peningkatan 30 persen berikutnya terjadi pada usia delapan tahun, dan 20 persen sisanya pada pertengahan atau akhir dasawarsa kedua.

Dari sini, sudah sepatutnya pendidikan karakter dimulai dari dalam keluarga, yang merupakan lingkungan pertama bagi pertumbuhan karakter anak.Setelah keluarga, di dunia pendidikan karakter ini sudah harus menjadi ajaran wajib sejak sekolah dasar.Anak-anak adalah generasi yang akan menentukan nasib bangsa di kemudian hari. Karakter anak-anak yang terbentuk sejak sekarang akan sangat menentukan karakter bangsa di kemudian hari. Karakter anak-anak akan terbentuk dengan baik, jika dalam proses tumbuh kembang mereka mendapatkan cukup ruang untuk mengekspresikan diri secara leluasa. 


\section{Metode dan Pendekatan Penelitian}

Penelitian ini menggunakan metode kualitatif.Metode kualitatif adalah metode riset yang sifatnya memberikan penjelasan dengan menggunakan analisis. Pada pelaksanaanya, metode ini bersifat subjektif dimana proses penelitian lebih diperlihatkan dan cenderung lebih fokus pada landasan teori.

Mengapa menggunakan metode kualitatif karena mengacu kepada

paradigma naturalistik alamiah yang bersumber pada pandangan fenomenologis khususnya yang berkaitan dengan teori yang di kembangkan (Spradley, 1980). Pandangan ini bersandar pada gejala-gejala yang menampakan diri, dimana peneliti berusaha memahami arti peristiwa dan kaitan-kaitannya dengan situasi tertentu dari perilaku seseorang atau sekelompok yang berhubungan

dengan pembentukan karakter dalam pembelajaran BCCT (Beyond Center and Circle Time), Spradley memiliki model dengan mengembangkan 12 tahap penelitian kualitatif tahapan tersebut dapat dilihat pada gambar berikut:

Adapun prosedur pengumpulan data berupa: pengamatan berperan serta, wawancara, pengumpulan dokumentasi, dan pembuatan catatan lapangan. Sedangkan teknik analisis datanya yaitu melakuakn analisis domain dan analisis taksonomi dan analisis tema.

Pendekatan Penelitian Didasarkan pada karakteristik dan fokus masalah yang diteliti mengenai pembiasaan nilai-nilai asmaul husna dalam pembentukan karakter religius maka penelitian ini menggunakan pendekatan kualitatif. Pendekatan kualitatif menurut Darmadi (2013, hlm. 286): Penelitian kualitatif adalah suatu proses penelitian dan pemahaman yang berdasarkan pada metodologi yang menyelediki suatu fenomena sosial dan masalah manusia. Penelitian kualitatif digunakan jika masalah belum jelas, untuk mengetahui makna yang tersembunyi, untuk memahami interaksi sosial, untuk mengembangkan teori, untuk memastikan kebenaran data, dan meneliti sejarah perkembangan.

Pemilihan pendekatan kualitatif ini tidak lain adalah untuk mengetahui sejauh mana pembentukan karakter siswa dan penulis berusaha untuk objektif dalam memperoleh data dan informasi mengenai kegiatan yang dilaksanakan di SDN 
TANGERANG 15. Pembentukan karakter tersebut tentu akan sangat sulit diukur bila dilakukan secara kuantitatif yang berdasarkan perhitungan angka, karena karakter merupakan hal yang ada di dalam diri sehingga dibutuhkan pendekatan yang mendalam. Selain itu karena penelitian ini ingin memahami masalah atau keadaan sekelompok individu atau orang sehingga bersifat sosial atau kemanusiaan, serta dalam hal ini permasalahan belum jelas sehingga perlu diadakan penelitian dengan pendekatan kualitatif.Efektivitas dari pelaksanaan pembiasaan nilai-nilai asmaul husna yang belum terlihat dan tersembunyi sehingga dipilihlah pendeketan kualitatif ini.

Dan juga menggunakan Metode Survei. Metode Survei adalah suatu metode yang digunakan untuk mendapatkan hasil riset dalam bentuk opini atau pendapat dari orang lain yang berinteraksi langsung dengan objek yang diamati. Tujuan utama dari metode ini adalah untuk mendapatkan gambaran umum melalui sampel beberapa orang. Dalam hal ini mengapa kita menggunakan metode ini dikarena kan kita sudah melakukan observasi atau wawancara ke salah satu wali murid peserta didik dan mendapatkan jawaban atau hasil riset dalam bentuk opini sang wali murid dengan alasan karena wali murid berinteraksi langsung dengan peserta didik setiap hari nya.

\section{HASIL DAN PEMBAHASAN}

Hasil diskusi dan pembahasan dari wawancara ini yaitu cara mengatasi siswa yang bandel, tidak sopan terhadap guru itu yang pertama bagaimana setiap kali siswa melakukan kesalahan, kita sebagai guru mengingatkan, menegur dan itu tidak bosan. setiap diingatkan kita beri tahu selalu terus mengingatkan kepada siswa yang melakukan kesalahan. Karena kita mendidik itu tidak semudah membaikan telapak tangan. Untuk mengetahui karakter siswa yang pendiam dan tidak terlalu banyak bicara yaitu dengan cara guru mengajak ngobrol siswa tersebut mau didengarkan atau tidak oleh siswa yang penting guru sudah mengajak berbicara si siswa tersebut karena semakin lama siswa akan merasa nyaman dengan guru. Semua guru beranggapan jika siswa belum berani berbicara berarti siswa tersebut belum merasa nyaman dan belum percaya kepada guru. Bagaimana karakter siswa yang bisa sukses sedangkan kesuksesan karakter siswa tidak di ukur karena sukses itu relatif, apa sukses setelah anak keluar, mungkin sekian 20 tahun 30 tahun ketemu dengan mereka, mereka 
masih welcome tidak terhadap guru tinggal tergantung relatif suksesnya dimana.Tujuan pendidikan karakter di sekolah adalah anak-anak itu memiliki karakter-karakter yang awal-awal kami membaca anak di kelas rendah begitu literasi, kita berharap setelah dibaca, mungkin memahami ada didalam diri dari anak kelak dewasa. Sebuah film anak dapat membentuk karakter siswa bisa karena dengan film anak lebih apresiasi untuk tanya jawab di kelas dari si anak seperti ingin meniru menjadi karakter yang ada di film itu. Pembentukan karakter dilakukan sejak dini karena sejak dini pikiran siswa masih bersih jadi guru lebih gampang memasukan halhal yang positif. Hal-hal yang positif itu akan terekam dimemorinya dan siswa akan melaksanakan didalam kehidupannya kelak. Selain orang tua guru juga harus ikut serta dalam pendidikan karakter anak karena tanggung jawab terhadap siswa itu ada pada guru, orang tua, dan masyarakat. Jadi guru harus ikut serta, orangtua dirumah, diluar rumah dan diluar sekolah ada si masyarakat. Itu sesuai dengan tanggung jawabnya, 3 komponen itu tidak lepas dari tanggung jawab kita untuk anak-anak. Sebuah kesuksesan ditentukan oleh pendidikan karakter itu tinggal suksesnya yang mana, sukses itu relatif kalau melihat dari karakter yang kita miliki kan anak mempunyai karakter yang baik, mudah-mudahan sukses, karena sukses tidak dalam berlimpah materi saja. Bisa saja sukses dalam hal lain. Dengan adanya pendidikan karakter dapat membentuk karakter yang ada dalam diri manusia, perlu, bagaimana hal-hal positif yang harus dimiliki oleh setiap individu itu harus diajarkan jadi kalau tidak diajarkan bagaimana dengan mereka. Pendidikan karakter itu penting, kita sebagai guru bisa menyisipkan pendidikan karakter itu dilangkah-langkah pada saat kbm, jadi betapa pentingnya pendidikan karakter itu untuk anak. Produk dari pendidikan karakter itu akan ada setelah dewasa.

\section{Kesimpulan}

Pembentukan karakter melalui pendidikan karakter pada dasarnya berangkat dari berbagai macam permasalahan yang menyangkut generasi muda di era globalisasi sekarang ini. Kondisi putra-putri bangsa semakin memprihatinkan dilihat dari cara pergaulan mereka, gaya hidup, penurunan semangat belajar, masalah narkoba, bahkan kriminalitas yang menjerat anakanak di bawah umur seakan sudah menjadi hal yang 
biasa belakangan ini. Melihat dari situasi kebanyakan generasi muda saat ini dan dengan adanya wacana pembentukan karakter pada pribadi bangsa, maka muncullah berbagai variasi dari pendidikan karakter. Dirumuskannya pendidikan karakter adalah guna membentuk bangsa yang kuat dan berkarakter, bermartabat, serta disegani di dunia internasional.Untuk mendapatkan bangsa dan negara semacam itu perlu penerapan pendidikan karakter yang benar.Di Indonesia sendiri pendidikan karakter telah cukup lama didengungkan dalam dunia pendidikan.Karakter merupakan aspek utama dalam membentuk kualitas seseorang untuk dapat menjadi insan yang mulia.Apabila kualitas diri seseorang baik dan senantiasa ditumbuh kembangkan, maka seseorang tersebut dapat menjadi manusia yang bermanfaat bagi lingkungan sekitar dan kemajuan bangsa.

\section{DAFTAR PUSTAKA}

Suparno. 2018. Analisis Faktor-Faktor Pembentuk Karakter Smart Siswa Di Sekolah Islam Terpadu. Jurnal Pendidikan Karakter Vol 8 No 12018

Maharani Ramadhanti, M Syarif Sumantri, Edwita. 2019. Pembentukan Karakter Dalam Pembelajaran BCCT (Beyond Center And Circle Time). Jurnal Educate Vol 4 No 12019 